Ann. Zootech., I974, 23 (2), I85-I92.

\title{
UDDER CONFORMATION, MILK YIELD AND MILK FRACTIONATION IN THE DAIRY EWE
}

\author{
R. SAGI and M. MORAG ( $\left.{ }^{1}\right)$ \\ Faculty of Agricultural Engineering, Technion, Haifa, Israel \\ Negev Institute for Arid Zone Research, Beer Sheva, Israel
}

SUMMARY

Dairy ewes of the Assaf breed were classified into 4 groups according to udder conformation. Criteria for classification was the depth of differentation between the 2 udder glands and the position of the teats (fig. I). Yield dropped and the relative size of the machine milk fraction (from $7^{2} \mathrm{p}$. Ioo to $4^{\mathrm{o}} \mathrm{p}$. Ioo at the a. m. milking and from $65 \mathrm{p}$. Ioo to $19 \mathrm{p}$. Ioo at the $\mathrm{p}$. m. milking) decreased as gland differentation became less defined and teats positioning become higher (fig. 4). A further experiment showed that if the milker's hand was inserted between the glands of ewes with ill defined glands and highly positioned teats the machine milk fraction became larger (from $50 \mathrm{p}$. Ioo to $69 \mathrm{p}$. Ioo at the a. m. milking and from $34 \mathrm{p}$. Ioo to $65 \mathrm{p}$. Ioo at the p. m. milking), at the expense of the machine strippings (fig. 5). The physiological and practical complications of these results are discussed.

\section{INTRODUCTION}

One of the most serious problems in dairy sheep farming is the unsatisfactory fractionation of milk yield in machine milked ewes. Machine stripping (in individual sheep of the Awassi breed) can be as high as $60 \mathrm{p}$. Ioo and hand stripping as high as $30 \mathrm{p}$. Ioo of the yield obtained at milking. Bad fractionation prevents the development of modern milking parlour systems (as for example in dairy cows) and in this way may prove to be a decisive factor in the decline of dairy sheep flocks.

During a series of studies on the effect of components of the milking machine on milk fractionation, we began to suspect that the pattern of milk fractionation may be related to udder conformation. Although sheep udders have been classified into conformation types (FYaI, VolCANI et SHARAV, I858 and MaLIK, I970), we are unable to find any report on the relationship between udder type and milk fractionation.

(1) Dr M. MoRAG died (24-4-73) shortly after summarizing this paper. 


\section{MATERIALS AND METHODS}

\section{Experiment 1}

The relationship between udder type and milkability was estimated in an experimental flock in Neve Ya'ar in the Southern foothills of the Galilee $\left(32^{\circ} 45^{\prime} \mathrm{N}, 35^{\circ} \mathrm{I} 2^{\prime} \mathrm{E}\right)$ in July, $197^{2}$.

The flock consisted of $\mathbf{I} 75$ weaned Assaf dairy ewes. The Assaf is a new breed developed from the Improved Awassi (FINCI, 1957) and the East Friesian breeds. The flock averaged 305 litres of milk (dairy production - not including suckling) and I.7 lambs per lambing in 1972. The flock was classified into 4 types on the basis of exterior udder conformation (fig. I).

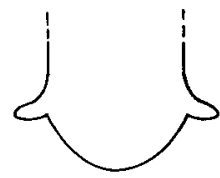

1

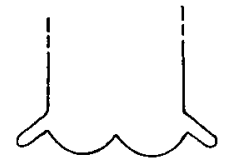

III

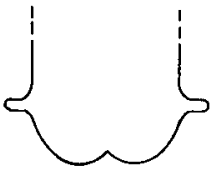

II

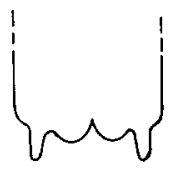

IV

FIG. I. - Schematic representation of udder types $I, I I, I I I$ and $I V$. (Experiment $\mathrm{I}$ )

FIG. I. - Représentation schématique des différents types de glande mammaire $I, I I, I I I$ et $I V$ (Expérience I)

Type I : Those ewes in which the teats were high up and which showed no differentiation between left and right glands ( 36 ewes).

Type II : Those ewes in which the teats were at a similar height but with a slight differentiation between the glands ( 72 ewes).

Type III : Those ewes in which the teats were lower and the glands were clearly divided (56 ewes).

Type IV : Those ewes in which the teats pointed downwards (as in a cow) and the glands were clearly divided ( 5 ewes).

Six ewes could not be classified into one of the described groups.

The ewes were milked into low-line recording jars which allowed separate estimates of machine milk and machine stripping. The former term refers to milk obtained by the machine without manual assistance whilst the second refers to the yield obtained by the machine in response to vigorous udder massage and pressure on the cups. Immediately after the teat cups were removed, hand stripping was carried out. Udder washing and foremilking were not practised. Milking was carried out using a (Alfa-Laval) monobloc liner in a stainless steel cup weighing r75 g. Vacuum was at $33 \mathrm{~cm} \mathrm{Hg}$ and pulsation at I 20 pulses a minute at a ratio of $50: 5^{\circ}$. The recording was carried out after an $8 \mathrm{~h}$ day interval and I $6 \mathrm{~h}$ night interval.

\section{Experiment 2}

The effect of supporting the udder of dairy ewes with an ill defined differentiation between glands was estimated using 8 weaned Assaf ewes. The sheep, all of type I (the best 8 animals in the group of 36 ewes used in experiment I) were divided at random into two groups. The first 
group was subjected to a treatment sequence, $\mathrm{ABA}$, and the second group to the sequence, $\mathrm{BAB}$. Treatment A consisted of a milking procedure as described in Experiment $\mathrm{I}$, whilst Treatment B consisted of a similar procedure except that the operator inserted his hand between the two glands so as to differentiated between the glands, as in Type III. The insertion of the hand also changed the angle of teat attachment (see figure 2). The hand was inserted when the teat cups

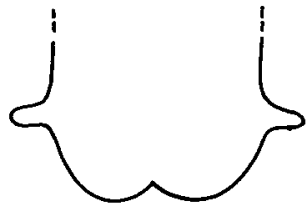

A

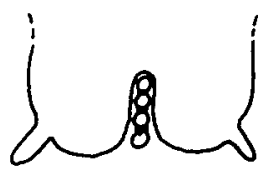

B

FIG. 2. - Schematic representation of Treatment $A$ (Type II with no udder support) and Treatment $B$ in which hand is inserted between udder halves to changes Type II into a pseudo-Type III. The angle of teat attachment is also affected (Experiment 2).

FIG, 2. - Représentation schématique du traitement $A$ (type II sans modification de l'écartement des glandes) et du traitement $B$ au cours duquel on introduit la main entre les 2 glandes transformant ainsi le type II en pseudo-type III. L'angle d'attache des trayons se trouve alors modifié (Expérience 2).

were applied and removed as soon as the flow of machine milk stopped. Each treatment period consisted of 4 days and milkings were carried out twice daily after an $8 \mathrm{~h}$ day and a I6 h night interval. All milkings were carried out by the same operators. Milking equipment was the same as in that described in Experiment $\mathbf{I}$. The experiment took place in Neve Ya'ar in july, 1972.

\section{RESULTS}

\section{Experiment 1}

The mean age and month of lactation of the ewes in the 4 groups at the time of the recordings were not significantly different. The total dairy yield and the yield of milk in the 3 fractions were subjected to an analysis of variance. The means for total yield are presented in figure 3 . Total dairy yield increased from $289 \mathrm{~g}$ in Type I to $493 \mathrm{~g}$ in Type IV after the $8 \mathrm{~h}$ interval $(\mathrm{P}<0.05)$ and from 620 to $945 \mathrm{~g}$ after the $\mathrm{I} 6 \mathrm{~h}$ interval $(\mathrm{P}<\mathrm{O}$.oI).

The means of the fractions expressed as a percentage of total diary yield are presented in figure 4 . The percentage of machine milk increased from I9 (after the $8 \mathrm{~h}$ interval) and $40 \mathrm{p}$. Ioo (after the $\mathrm{I} 6 \mathrm{~h}$ interval) in Type I to 65 and $72 \mathrm{p}$. Ioo respectively in Type IV. Machine stripping decreased from 46 and 32 in Type I to 24 and $\mathrm{I} 2 \mathrm{p}$. Ioo in type IV. Similarly, the percentage of hand stripping dropped from 35 and $28 \mathrm{p}$. Ioo in Type I to II and I6 p. Ioo in Type IV. All differences in the percentages of the fractions within a given milking were highly significant $(\mathrm{P}<0.00 \mathrm{I})$.

\section{Experiment 2}

The total dairy yield after an $8 \mathrm{~h}$ and a $\mathrm{I} 6 \mathrm{~h}$ interval and the percentage of machine milk, machine and hand stripping were subjected to an analysis of variance as suggested by FEDERER (I955). The total dairy yield was somewhat higher for the treat- 

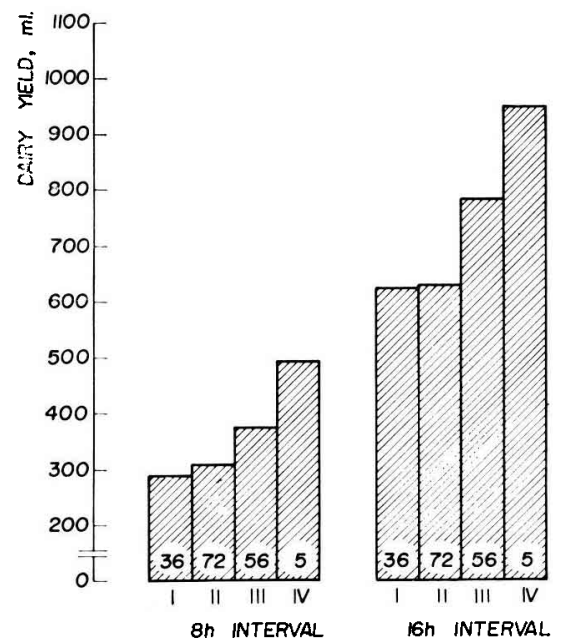

FIG. 3. - Total dairy yield in udder types $I, I I, I I I$ and $I V$ after $8 h$ and $16 h$ intervals The number of ewes of each udder type is shown in the columns of the histogram (Experiment 1 )

FIG. 3. - Production totale de lait pour les types de glande mammaire I, II, III et IV après des intervalles de $8 \mathrm{~h}$ et $16 \mathrm{~h}$

On trouvera le nombre de brebis avec chaque type de glande mammaire dans les colonnes de l'histogramme (Expérience I)

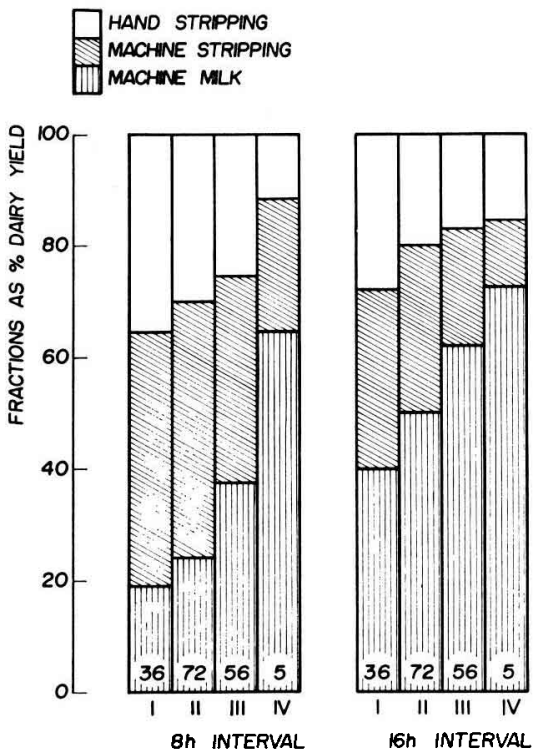

FIG. 4. - Milk fractions (Machine milk, machine stripping and hand stripping) in udder types $I, I I, I I I$, and IV expressed as a pircentage of total dairy yield. The estimates were made after $8 \mathrm{~h}$ and $16 \mathrm{~h}$ intervals. The number of ewes of each type is shown in the columns of the histogram (Experiment $r$ ).

FIG. 4. - Fractions de lait (" lait-machine ", égouttage machine et manuel) pour les types de glandes mammaires $I, I I, I I I$ et $I V$ exprimées en pourcentage de production totale de lait. Les estimations ont été réalisées à intervalles de 8 et $16 \mathrm{~h}$. Le nombre de brebis de chaque type est indiqué dans les colonnes de l'histogramme (Expérience I). 
ment, (5II g versus $475 \mathrm{~g}$ after the $8 \mathrm{~h}$ interval and $706 \mathrm{~g}$ versus $687 \mathrm{~g}$ after the $\mathrm{I} 6 \mathrm{~h}$ interval). The differences, however, were not significant $(\mathrm{P}>0.05)$. The changes in the fractions are shown in figure 5 .

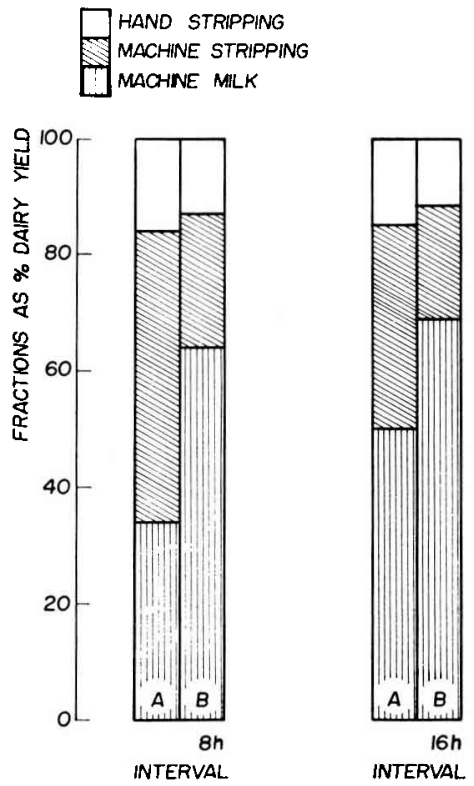

Fig. 5. - Milk fractions (machine milk, machine stripping and hand stripping) expressed as a percentage of teat and dairy yield when ewes were milked without or with hand support between the udder glands (Experiment 2).

FIg. 5. - Fractions de lait (" lait-machine ", égouttage machine et manuel) en pourcentages de production par trayon et production de lait totale lorsque les brebis ont eté soumises à une traite avec ou sans introduction de la main entre les 2 glandes (Expérience 2 ).

Support of the udder during machine milking caused an increase in the percentage of machine milk from 34 (after the $8 \mathrm{~h}$ interval) and $5^{\circ} \mathrm{p}$. Ioo (after the I6 h interval) to 64 and $69 \mathrm{p}$. Ioo respectively and a decrease in the amount of machine stripping from 50 and $35 \mathrm{p}$. Ioo to 23 and $19 \mathrm{p}$. I00. The differences in the percentages of the machine milk and machine stripping were found to be highly significant $(\mathrm{P}<0.00 \mathrm{I})$. The changes observed in the amounts of hand stripping (a decrease from $\mathrm{I} 6$ and $\mathrm{I} 5 \mathrm{p}$. Ioo to $\mathrm{I}_{3}$ and $\mathrm{I} 2 \mathrm{p}$. $\left.\mathrm{roo}\right)$ were not significant $(\mathrm{P}>0.05)$.

\section{DISCUSSION}

\section{Characteristics of a dairy animal}

A good dairy animal is one which gives most of its yield in response to the stimulus of machine milking. Modern dairy cows fall into this category and can maintain high lactation yields without need for either machine or hand stripping. This has been achieved by a combination of selection and of improvements in milking machine design. 
The situation with sheep is quite different. Most dairy sheep are, in fact, dual purpose animals and are required, at least in early lactation to provide milk for a suckling lamb as well as for dairy production (FoLMAN, VolcaNI and Eyal, I966 for description of various suckling/milking regimes). In such a husbandry system it is difficult to select for a dairy type in the terms defined above. Furthermore as fatlamb sales can account for up to $5^{\circ} \mathrm{p}$. Ioo of the flock income, the tendency may be to select for a good "mother" (i. e. an animal who guarantees a good growth rate in its lamb) rather than for a good " dairy " type. The suggestion that dairy ewes should be weaned at birth and that the lamb should be artificially reared (MoraG and EYAL, I97I) allows for a selection programme based entirely on dairy performance to be introduced.

\section{The physiological and anatomical factors in fractionation}

It is not clear whether bad fractionation in dairy sheep is due to anatomical and/or to physiological factors. LABUSSIÈRE, MARTINET and DENAMUR (I969) believe that fractionation patterns are dependent on the presence or absence of the neurohormonal reflex of milk ejection. They report that at least in the Préalpes sheep population there are two distinct types of ewe. The first is characterized by low yields, by relatively large stripping fraction and by a single flow of milk in the machine milk fraction (these are known as " single-peak " ewes). The second type has higher yields, relatively smaller stripping fractions and two distinct flows of milk in the machine milk fraction (" double-peak " ewes). The French authors contend that single peak ewes do not exhibit milk ejection in response to machine milking and that machine milk is entirely composed of cisternal milk, that is milk present in the sinuses prior to milking. The "two peak ewe " is believed to exhibit milk ejection : the first peak consists of cisternal milk whilst the second one consists of alveolar milk newly ejected in response to the stimulus of milking. Although no direct measurements of blood levels of oxytocin to support these suggestions have been reported, the indirect experimental evidence presented by the French authors is very strong. It may be that physiological endocrine factors are of importance in the fractionation of milk in the Préalpes ewes. The situation with the high yielding Awassi and Assaf ewes is not so clear. Our observations in these breeds show that although both single or double peak ewes can be found, the frequency of double peak animals is far lower than in France. Furthermore, single peak animals are not necessarily lower yielding than double peak animals. It is improbable that high yielding ewes of these breeds could maintain the level of milk secretion only on the basis of cisternal milk and without the ejection of alveolar milk. We suggest that most of the Israeli ewes are, in fact, " double peak " ewes in which the two peaks are telescoped; that is the newly ejected milk reaches the cisterns before all the cisternal milk has been removed. Awassi and Assaf ewes have, however, relatively large cisterns.

The present experiments suggest that anatomical factors are also of importance. The conformaton of the sheep udder has a profound effect on both the dairy yield and on the fractionation of milk. Furthermore, the udder type which gave the highest yields was also the udder type which had the most satisfactory fractionation. The fractionation of yield in Type IV - at least at the morning milking is similar to the performance obtained by cow milking machines. On the other hand, a large number 
of ewes in the flock have low yields and very bad fractionation. The development of more efficient milking machines and especially milking routine cause a partial shift of milk from the hand stripping fraction and from the machine stripping fraction to the machine milk fraction. However, the improvement in fractionation which can be achieved in this manner is probably limited. In this context automated milking systems in which no stripping is carried out (as is now usual in many dairy cattle herds) could only be introduced into flocks with udder types IV and possibly using improved machine in type III. The loss of yield in the other types would be too great.

In the second experiment it was shown that the insertion of a support between the glands changed the pattern of fractionation in Type II ewes to one similar to that in Type III. The improvement could be due to a local mammary and/or central hormonal effect. Thus the insertion of the hand could bring milk which is located in cistern below the level of the teat exit flow out of the teat, or alternatively the treatment could lead to release of oxytocin and cause a further ejection of milk during the time that the machine milk fraction is being removed. From observation of the flow of machine milk into the recording jars we got the impression that only a local mechanism was involved. Confirmation of this could be obtained by using a milkflow recording system (e. g. LABUSSIERE and MARTINET, I964). Further work on the effect of age and stage of lactation on udder type and fractionation is in progress. Furthermore, the heritability of udder type and milk ability is being measured in both improved Awassi and Assaf breeds.

Rę̧u pour publication en novembre 1973.

\section{ACKNOWLEDGEMEN'T}

We are grateful to Dr. J. Martinet for discussion and for his comments on the manuscript.

RÉSUMÉ

\section{CONFORMATION DE LA GLANDE MAMMAIRE ET PRODUCTION DE LAIT \\ CHEZ LA BREBIS LAITIÈRE}

Les brebis laitières d'un troupeau de race Assaf sont classées (4 groupes, fig. I) en fonction de la conformation de leur glande mammaire.

Les critères de ce classement sont :

I. l'importance de la séparation morphologique entre les deux glandes;

2. la position des trayons.

La production décroît et l'importance relative de la fraction "lait-machine " diminue (de 70 à 40 p. I 00 pour la traite du matin, de 65 à I9 p. Ioo pour la traite du soir) lorsque la séparation entre les deux glandes devient de moins en moins marquée et la position des trayons plus latérale (fig. 4).

Une expérience de traite au cours de laquelle le trayeur insère la main verticalement entre les deux glandes, dans le cas des animaux à séparation mal définie et à trayons hauts, montre 
que le "lait machine " augmente (de 50 à 69 p. Ioo le matin, de 34 à 65 p. too le soir) par une forte réduction à I' " égouttage machine ".

L.es conséquences physiologiques et pratiques de ces observations sont discutées.

\section{REFERENCES}

Eyal E., Volcani R.,Sharav E., I958. The secretion of milk and problems of milking efficiency in sheep. Hanoked, 40, 7-Io (In Hebrew).

Federer W. T., 1955. Experimental design. The Macmillan Company, New York, p. 443-444.

Fincr M., 1957. The improvement of the Awassi breed of sheep in Israel. Bull. Res. Counc. Israel, 68, I-IO6.

Folman Y., Volcani R,, Eyal E., I966. Mother-offispring relationships in Awassi sheep. I. The effect of different suckling regimes and time of weaning on the lactation curve and milk yield in dairy flocks. J. agric. Sci. Camb., 67, 359-368.

Labussière J., Martinet J., I964. Description de deux appareils permettant le contrôle automatique des débits de lait au cours de la traite à la machine. Premiers résultats obtenus chez la Brebis. Ann. Zootech., 13, I99-212.

Labussière J., Martinet J., Denamur R., I969. The influence of the milk ejection reflex on the flow rate during the milking of ewes. J. Dairy Res., 36, I9r-201.

MALIK J., r97o. Relation between udder form properties and milk ability in fine wool sheep. Wedecké práce Vyskumného ustavu ovciarskeho v Trencine, 5, 53-6r (In Czech).

Morag M., EYal E., I97I. Post partum conception in lactating Awassi and East Friesian X Awassi dairy ewes. J. Agric. Sci., Camb., 7y, Iog-1 I6.

Ovesen E., 1972. Milking ability in relation to size and st. re of teats. Anim. Prod., 15, 25 I-257. 